Pobrane z czasopisma Studia Iuridica Lublinensia http://studiaiuridica.umes.pl Data: 26/04/2023 01:21:21

\title{
STUDIA IURIDICA LUBLINENSIA
} VOL. XXX

1

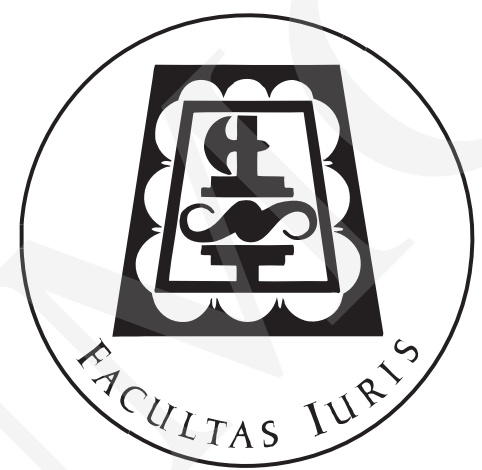


Pobrane z czasopisma Studia Iuridica Lublinensia http://studiaiuridica.umes.pl Data: 26/04/2023 01:21:21

EDITOR-IN-CHIEF

Beata Jeżyńska, Maria Curie-Skłodowska University, Poland

MANAGING EDITOR (SECRETARY)

Jarosław Kostrubiec, Maria Curie-Skłodowska University, Poland

HEAD OF THE EDITORIAL BOARD

Boštjan Brezovnik, New University, Slovenia

EDITORIAL BOARD (ASSOCIATE EDITORS)

Muhammad Akib, University of Lampung, Indonesia

Alexander Bröstl, Šafárik-University Košice, Slovakia

Claudia Morgana Cascione, University of Bari Aldo Moro, Italy

Tomasz Demendecki, Maria Curie-Skłodowska University, Poland

John Diamond, Edge Hill University, England

Max-Emanuel Geis, Friedrich-Alexander University Erlangen-Nürnberg, Germany

Samuel Gregg, Acton Institute, United States

Hakan Hakeri, Istanbul Medeniyet University, Turkey

Angel Sánchez Hernández, University of La Rioja, Spain

István Hoffman, Eötvös Loránd University, Hungary

Eliza Komierzyńska-Orlińska, Maria Curie-Skłodowska University, Poland

Ivan Koprić, University of Zagreb, Croatia

Andrzej Korybski, Maria Curie-Skłodowska University, Poland

Grzegorz Kozieł, Maria Curie-Skłodowska University, Poland

Marek Kulik, Maria Curie-Skłodowska University, Poland

Bartosz Liżewski, Maria Curie-Skłodowska University, Poland

Bogdana Neamtu, Babeș-Bolyai University, Romania

Ireneusz Nowikowski, Maria Curie-Skłodowska University, Poland

David Partlett, Emory University, United States

Sławomir Patyra, Maria Curie-Skłodowska University, Poland

Dušan Popović, University of Belgrade, Serbia

Anna Przyborowska-Klimczak, Maria Curie-Skłodowska University, Poland

Krisztina Rozsnyai, Eötvös Loránd University, Hungary

Catalin-Silviu Sararu, Bucharest University of Economic Studies, Romania

Małgorzata Stefaniuk, Maria Curie-Skłodowska University, Poland

Trinidad Vázquez Ruano, University of Jaén, Spain

John Vervaele, Utrecht University, The Netherlands

Isabel Viola Demestre, University of Barcelona, Spain

Andrzej Wrzyszcz, Maria Curie-Skłodowska University, Poland

STATISTICAL EDITOR

Paweł Wroński, Maria Curie-Skłodowska University, Poland

ACADEMIC ADVISORY BOARD

Andrzej Jakubecki (Chairperson), Maria Curie-Skłodowska University, Poland

Anatolij Berlacz, Taras Shevchenko National University of Kyiv, Ukraine

Toshiyoshi Kashiwazaki, Tokyo University of Science, Japan

Vilem Knoll, University of West Bohemia, Czech Republic

Wiaczesław Komarow, Yaroslav Mudryi National Law University, Ukraine

Leszek Leszczyński, Maria Curie-Skłodowska University, Poland

Igor Michajłowicz Mackiewicz, Kutafin Moscow State Law University, Russia

John McClellan Marshall, The Honorable Senior Judge, United States

Jean Denis Mouton, University of Nancy 2, France

Vytautas Nekrošius, Vilnius University, Lithuania

Bernd Oppermann, University of Hanover, Germany

NETWORK EDITOR

Paweł Szczęśniak, Maria Curie-Skłodowska University, Poland

Editorial Board Address:

Faculty of Law and Administration at Maria Curie-Skłodowska University, pl. Marii Curie-Skłodowskiej 5 20-031 Lublin phone: +48 8153751 26, +48 815375439 www.studiaiuridica.umcs.pl 
Pobrane z czasopisma Studia Iuridica Lublinensia http://studiaiuridica.umes.pl Data: 26/04/2023 01:21:21

FACULTY OF LAW AND ADMINISTRATION AT MARIA CURIE-SKŁODOWSKA UNIVERSITY

\section{STUDIA IURIDICA LUBLINENSIA}

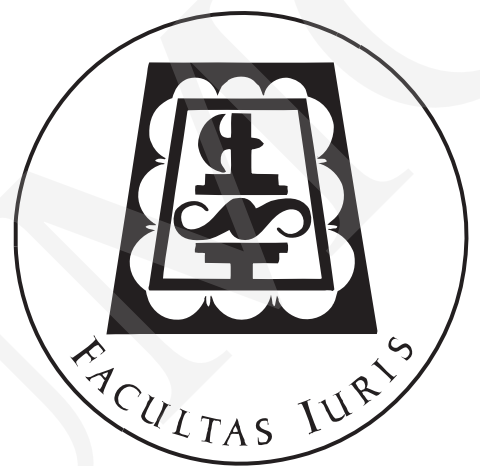

\section{VOL. XXX}

1

MARIA CURIE-SKŁODOWSKA UNIVERSITY PRESS 
Pobrane z czasopisma Studia Iuridica Lublinensia http://studiaiuridica.umes.pl Data: 26/04/2023 01:21:21

\author{
Editor / Anna Adamczyk \\ Design of the front page and title pages / Marta Kwiatkowska \\ Typesetting / Marcin Wachowicz \\ The journal is indexed at: \\ Scopus; BazHum; BazEkon; Index Copernicus International (ICI Journals Master List); Google Scholar; \\ POL-index; The Central European Journal of Social Sciences and Humanities (CEJSH); \\ Central and Eastern European Online Library (CEEOL);
}

The European Reference Index for the Humanities and the Social Sciences (ERIH PLUS); WorldCat

Printed version is the primary version of all volumes of "Studia Iuridica Lublinensia"

(C) by Maria Curie-Skłodowska University Press, Lublin 2021

ISSN: $1731-6375$

Trade Department

MARIA CURIE-SKŁODOWSKA UNIVERSITY PRESS

ul. Idziego Radziszewskiego 11

20-031 Lublin, Poland

phone: +48 (81) 5375304

www.umcs.lublin.pl/wydawnictwo

e bookstore:

www.wydawnictwo.umcs.eu

Sales Department: phone/fax +48 (81) 5375302

e-mail: wydawnictwo@umcs.eu

Printed

Mazowieckie Centrum Poligrafii Wojciech Hunkiewicz

ul. Lisi Jar 29, 05-270 Marki

Nakład: 80 egz. 


\title{
Table of Contents
}

\author{
Spis treści
}

\begin{abstract}
Articles
JOANNA BRZEZIŃSKA

Women as Perpetrators of Crimes in Poland: An Analysis from a Statistical

Perspective

Kobiety jako sprawczynie przestepstw w Polsce. Analiza z perspektywy statystyk

\section{BOŻENA CZECH-JEZIERSKA}

The Class-Based Approach to Roman Criminal Law

Wokót problematyki klasowości w rzymskim prawie karnym

\section{EWA GMURZYŃSKA}

Analysis of the Causes of Conflicts at Universities and Alternative Methods of Resolving Them. Part I: Mediation in Academic Disputes Analiza przyczyn konfliktów na uczelniach wyższych $i$ alternatywne sposoby ich rozwiązywania. Część I. Mediacja w sporach akademickich
\end{abstract}

\section{ISTVÁN HOFFMAN, ISTVÁN BALÁZS}

Administrative Law in the Time of Corona(virus): Resiliency of the Hungarian Administrative Law?

Prawo administracyjne w epoce koronawirusa. Jaka jest odporność (skuteczność) węgierskiego prawa administracyjnego?

\section{EWA KOZERSKA, KATARZYNA DZIEWULSKA}

The State National Council and the Polish Committee of National Liberation in a State Governed by the Rule of Law: Positions of Legal Scholarly Opinion Krajowa Rada Narodowa i Polski Komitet Wyzwolenia Narodowego w państwie prawa. Stanowiska doktryny

\section{EMIL KRUK}

Polish and Estonian Regulations on Homeless (Stray) Animals 


\section{BARTOSZ KWIATKOWSKI}

Legal Act as the Subject of Mythologization: Remarks on the Reception of the JUST Act of 2017 in Poland

Akt prawny jako przedmiot mitologizacji - uwagi na temat recepcji tzw. ustawy 447 na gruncie polskim

\section{PAWEŁ LESIŃSKI}

The Question of Civil Rights in the Views of Robert von Mohl

Problematyka praw obywatelskich $w$ świetle pogladów Roberta von Mohla

\section{ELŻBIETA LOSKA}

Inconvenient Witnesses: Testimonies of Slaves in a Criminal Trial During the Republic and the Principate

Niewygodni świadkowie - zeznania niewolników w procesie karnym $w$ okresie

Republiki i Pryncypatu

\section{DARIUSZ MAKIŁŁA}

Poland after the Thirteen Years' War (1454-1466): The Scope of Political and Structural Changes

Polska po wojnie trzynastoletniej (1454-1466). Zakres zmian ustrojowych i politycznych

\section{AGATA PRZYLEPA-LEWAK}

Legal-Sociological Research of the Prestige of Law

Socjologiczno-prawne badania prestiżu prawa

\section{MARÍA RUIZ ESTÉVEZ}

Comparison between the Polish-Lithuanian Constitution of 3 May 1791 and the Spanish Constitution of 19 March 1812

Porównanie polsko-litewskiej Konstytucji z 3 maja 1791 r. z hiszpańską Konstytucją z 19 marca $1812 r$.

\section{BRONISŁAW SITEK}

Servus publicus and servus privatus in Ancient Rome: Legal Status and Social Status

Servus publicus a servus privatus $w$ antycznym Rzymie. Status prawny a status społeczny

\section{DARIUSZ SŁAPEK}

Solidarism vs Marxism: "Legal Views of Slaves and Roman Proletarians" by Borys Łapicki Revisited

Solidaryzm vs marksizm, czyli o „Pogladach prawnych niewolników i proletariuszy rzymskich” Borysa Eapickiego raz jeszcze

\section{GRZEGORZ SMYK}

An Attitude of Polish Society Towards Russian Bureaucracy in the Kingdom of Poland after the January Uprising

Stosunek społeczeństwa polskiego do biurokracji rosyjskiej w Królestwie Polskim po powstaniu styczniowym 


\section{MAGDALENA SUROWIEC}

Cessio legis During Court Proceedings for Payment: Withdrawal of the Suit with

a Waiver of the Claim Resulting in Damage to the Purchaser of the Claim

Cessio legis w trakcie procesu o zapłatę. Cofnięcie pozwu ze zrzeczeniem się roszczenia przez zbywcę skutkujące wyrządzeniem szkody nabywcy wierzytelności

\section{ŁUKASZ SZYMAŃSKI}

Comments on Wojciech Dzieduszycki's Reflections on the State and Law

Uwagi o rozważaniach Wojciecha Dzieduszyckiego o państwie i prawie

\section{MARIUSZ WIECZOREK}

Some Aspects of Labour Law's Protective Function at the Time of COVID-19

Niektóre aspekty ochronnej funkcji prawa pracy w dobie COVID-19

\section{KATARZYNA WOJEWODA-BURACZYŃSKA}

Flat-Rate Tax on Ship Construction or Ship Reconstruction as a New Institution of

Polish Tax Law

Zryczaltowany podatek $w$ zakresie budowy statku lub przebudowy statku jako nowa instytucja polskiego prawa podatkowego

\section{AGNIESZKA WOLOSZYN-CICHOCKA}

Access to Patient's Medical Records in the Light of the Case Law of Administrative Courts

Dostęp do dokumentacji medycznej pacjenta w świetle orzecznictwa sądów administracyjnych

\section{BARTOSZ ZALEWSKI}

If a Maidservant "Dies a Horrible Death": Canon 5 of the Synod of Elvira in the Light of the Norms of Roman Criminal Law

Gdy niewolnica , wyzionie ducha w mękach" - kanon 5 synodu w Elwirze w świetle norm rzymskiego prawa karnego

\section{Glosses}

\section{EWA KATARZYNA CZECH}

Wykonywanie obowiązków ustawowych pomimo braku wydanych przepisów wykonawczych w zakresie prowadzenia wizyjnego systemu miejsca magazynowania odpadów. Glosa do wyroku Wojewódzkiego Sądu Administracyjnego w Białymstoku z dnia 9 czerwca 2020 r. (II SA/Bk 16/20, CBOSA)

Performance of Statutory Obligations Despite the Lack of Issued Executive Regulations Regarding the Operation of Visual System for the Place of Waste Storage: Gloss to the Judgement of the Voivodeship Administrative Court in Bialystok of 9 June 2019 (II SA/Bk $16 / 20, C B O S A$ ) 
Pobrane z czasopisma Studia Iuridica Lublinensia http://studiaiuridica.umes.pl Data: 26/04/2023 01:21:21

\section{BARTOSZ KUŚ}

Opodatkowanie nabycia nieruchomości w drodze działu spadku. Glosa do wyroku Naczelnego Sądu Administracyjnego z dnia 13 października 2015 r. (II FSK 2133/13, LEX nr 1808541)

Taxation of Acquisition of Immovable Property by Inheritance Division: Gloss to the Judgement of the Supreme Administrative Court of 13 October 2015 (II FSK 2133/13, LEX no. 1808541)

\section{MARZENA ŚWISTAK}

Obudowa górnicza jako odrębny od wyrobiska obiekt - konstrukcja oporowa, podlega opodatkowaniu podatkiem od nieruchomości. Glosa aprobująca do wyroku Naczelnego Sądu Administracyjnego z dnia 10 stycznia 2020 r. (II FSK 532/18, LEX nr 2777589)

The Mining Support May Be Classified as a Separate to Post-Mining Pit Retaining Structure and is Subjected to the Property Tax: The Approving Gloss to the Judgement of the Supreme Administrative Court of 10 January 2020 (II FSK 532/18 LEX no. 2777589) 